\title{
Share Auto Rickshaw Transport Service
}

\author{
${ }^{1}$ Dr. P. Ponraj, M.Com., M.Phil., M.B.A., Ph.D., Assistant Professor, Department of Commerce \& Research Centre, \\ Sourashtra College (Autonomous), Madurai - 625004.
}

\author{
${ }^{2}$ Mr. M. Sankara Narayanan, M.Com. M.Phil. Assistant Professor, Department of Corporate Secretaryship, Guru Nanak \\ College (Autonomous), Chennai - 600042.
}

\begin{abstract}
Transport in India is a compulsion as well as convenience. Public transport is still the primary mode of transport for population and India's public transport system are the most heavily exploited in the world. As India is a developing economy, road transport justifies a high precedence as it forms the strength of both the passenger transport and freight movement. Private division operators are also occupying a part in the passenger services in the country. Share autorickshaws are mostly found only in capital cities until one decade ago. Now it is a common sight that even in semi-urban areas share auto-rickshaws are plying connecting the network of rural areas. The present article has drawn its strength from such a social background and thus assumed a greater social relevance to-day.
\end{abstract}

Keywords: Share auto-rickshaws, employment opportunities, rural areas, private sector and transport

\section{Introduction}

Transport in India is a vital part of the nation's economy with a land area of 32,87,240 km which means $(12,69,210$ Square Meters) and a predictable population of 1.27 billion in 2013. Since the economic liberalization of the 1990's, development of groundwork within the country has developed at a rapid stride and today there is a wide variability of modes of transportation by land, water and air. Public transport is still the primary mode of transport for most of the people and India's public transport system are amongst the most heavily employed in the world.

India with the vast stretches of roads connecting nook and corner of the country, road transport has a vital role to play in the expansion and opening up of background and interior or distant areas of the country. The private sector operators are also occupying a part in the passenger services in the country. The urban transport system is predominantly operated by the private agencies particularly by taxis and share auto-rickshaws.

Share auto-rickshaws are mostly found only in capital cities until one decade ago. Now it is a common sight that even in semi-urban areas share auto-rickshaws are plying connecting the network of rural areas.

The expansion of residential areas, distant location of schools and colleges, and life-style changes even among the rural masses have paved the way for the preference of share auto-rickshaws even to reach their destination of shortest distance.

Besides serving the different sectors of the society, it provides self employment to lakhs of people especially youth. There is a tendency also much evident that school drop outs, and educated youths mostly preferring share auto-rickshaws for their livelihood as it offer sample scope of immediate self-employment either by owning or hiring share auto-rickshaw.

The tremendous developments that are taking place in education, health, tourism and construction sectors indicate an impressive population development in India in respect of income and employment. This makes the millions of people in the state utilizing all modes of transport including share auto-rickshaws transport everyday.

The present article by focusing over the share auto-rickshaw transport service would help bring to light the factors such as employment opportunities offered by the service, the socio-economic conditions of the share auto-rickshaw drivers, their problem, the satisfaction level on their jobs and other related aspects serving as a broad base for government intervention and action wherever necessary. Therefore, the present article has drawn its strength from such a social background and thus assumed a greater social relevance to-day.

\section{Share auto-rickshaws in India}

Most of the Indian auto-rickshaws are not having doors or seatbelts. They are usually black and yellow in color and have a covering on the top. Their design differs significantly from one place to another. In some places, they have an extra floorboard on the seat to lodge a fourth traveler. Share auto-rickshaws which are used for driving children to school generally have two extra seats/planks like narrow brackets, one facing the main seating space and one to the other side. Such share auto-rickshaws may transport up to 20 children to school. In India it is common to find mechanics shop around every corner, thus allowing share autowallahs easy access to spot-repairs. As a mode of transport the share auto-rickshaws is turning out to be a major employer in India. Many graduate youths drive share auto-rickshaws. All major banks of India offers loan to buy one under self-employment schemes.

Nagpur in India has the highest number of share autos in the country. In Bangalore alone, nearly 3 lakh drivers depend upon auto transport service for their livelihood.

\section{Review of literature}

The past studies found in the present article were reviewed by the researcher and presented in this section.

1. Jaisen in his research article titled "The City Rickshaw" stated that auto rickshaws were much more humble and economic vehicle, safe for both drivers and passengers and appropriate to inner-city use, of all kinds of transportation.

2. Anvita Anand and Rajendra Ravi, in their article titled "Auto-rickshaw drivers in Delhi" mentioned that it would be possible for the drivers to render services efficiently and effectively in the interest of the people as well as the interest of the country by fixing the electronic meters in their auto-rickshaws. 
3. In wikipedia it is reported that, the traffic regulating authorities has tried to implement prepaid schemes where the passengers pay pre-determined auto-fares to some central authority and board the autos in metro cities.

\section{Objectives of the study}

The following are the major objectives of the study.

i) To understand the employment opportunities offered by the share auto-transport service.

ii) To know the profile of sample respondents across their socio-economic factors.

iii) To measure the satisfaction level of share auto-rickshaw driver respondents and to identify their problems.

iv) To offer propositions based on the conclusions of the study.

\section{Hypothesis of the study}

i) The age of the respondents does not inspiration their level of fulfillment.

ii) The educational qualification of the respondents does not affect their level of fulfillment.

iii) The type of religion of the respondents does not influence their level of fulfillment.

iv) Marital status of the respondents does not influence their level of fulfillment.

v) The size of the family of the respondents does not influence their level of fulfillment.

vi) The residential status of the respondents does not influence their level of fulfillment.

vii) The status of ownership of share auto of the respondents does not influence their level of fulfillment.

viii) The source of finance of the respondents does not influence their level of fulfillment.

\section{Measurement of satisfaction level of respondent share auto-rickshaw drivers}

Sample respondents taken for the present article are 50. The measurement level of satisfaction of share auto-rickshaw drivers would help to understand their different levels of satisfaction over their job with a specific analysis of understanding across their socio-economic factors.

\subsection{Age of sample respondents}

The distributions of sample respondents according to their age are given in table 6.1

Table 6.1

Distribution of sample respondents according to their level of age

\begin{tabular}{|c|c|c|c|}
\hline Sl.No. & Level of age & Number & Percentage \\
\hline 1 & Below 25 & 31 & 62 \\
\hline 2 & Above 25 & 19 & 38 \\
\hline \multicolumn{2}{|c|}{ Total } & $\mathbf{5 0}$ & $\mathbf{1 0 0}$ \\
\hline
\end{tabular}

Below 25 is the dominating age group in the sample. It can be concluded that the relationship between the age of the respondents and their level of satisfaction is not statistically significant.

\subsection{Educational qualification of sample respondents}

The distribution of sample respondents according to their educational qualification is given in table 6.2.

\section{Table 6.2}

Distribution of sample respondents according to their educational qualification

\begin{tabular}{|c|c|c|c|}
\hline Sl.No. & Educational qualification & Number & Percentage \\
\hline 1 & Schooling & 15 & 30 \\
\hline 2 & College educated & 35 & 70 \\
\hline \multicolumn{2}{r|}{ Total } & $\mathbf{5 0}$ & $\mathbf{1 0 0}$ \\
\hline
\end{tabular}

Sample respondents who have educational qualification up to college level are dominating in the sample.

It clearly indicates that the association between the educational qualification of the respondents and their level of satisfaction is statistically significant.

\subsection{Religion of sample respondents}

The distribution of sample respondents according to their religion is given in table 6.3

\section{Table 6.3}

Distribution of sample respondents according to their religion

\begin{tabular}{|c|c|c|c|}
\hline Sl.No. & Kinds of religion & Number & Percentage \\
\hline 1 & Hindu & 21 & 42 \\
\hline 2 & Muslim & 19 & 38 \\
\hline 3 & Christian & 10 & 20 \\
\hline \multicolumn{2}{r|}{ Total } & $\mathbf{5 0}$ & $\mathbf{1 0 0}$ \\
\hline
\end{tabular}

Sample respondents belong to Hindu are dominating in the sample. It can be concluded that the association between the religion of the respondents and their level of satisfaction is statistically significant.

\subsection{Marital status of sample respondents}

The distribution of sample respondents according to their marital status is given in table 6.4 
Table 6.4

Distribution of sample respondents according to their marital status

\begin{tabular}{|c|c|c|c|}
\hline Sl.No. & Marital Status & Number & Percentage \\
\hline 1 & Married & 37 & 74 \\
\hline 2 & Unmarried & 13 & 26 \\
\hline \multicolumn{2}{|c|}{ Total } & $\mathbf{5 0}$ & $\mathbf{1 0 0}$ \\
\hline
\end{tabular}

Sample respondents belong to the married are dominating in the sample. It is concluded that the association between the marital status of the respondents and their level of satisfaction is statistically significant.

6.5 Size of the family of sample respondents

The distribution of sample respondents according to their size of family is given in table 6.5

Table 6.5

Distribution of sample respondents according to their size of family

\begin{tabular}{|c|c|c|c|}
\hline Sl.No. & Size of the family & Number & Percentage \\
\hline 1 & Up to 4 & 39 & 78 \\
\hline 2 & Above 4 & 11 & 22 \\
\hline \multicolumn{2}{|c|}{ Total } & $\mathbf{5 0}$ & $\mathbf{1 0 0}$ \\
\hline
\end{tabular}

Sample respondents who have size of the family up to 4 are dominating in the sample. It can be concluded that the association between the size of the family of the respondents and their level of satisfaction is not statistically significant.

6.6 Residential status of sample respondents

The distribution of sample respondents according to their residential status is given in table 6.6

Table 6.6

Distributions of sample respondent according to their residential status

\begin{tabular}{|c|c|c|c|}
\hline Sl.No. & Residential status & Number & Percentage \\
\hline 1 & Own house & 10 & 20 \\
\hline 2 & Rented house & 21 & 42 \\
\hline 3 & Leased house & 19 & 38 \\
\hline \multicolumn{2}{|c|}{ Total } & $\mathbf{5 0}$ & $\mathbf{1 0 0}$ \\
\hline
\end{tabular}

Sample respondents belong to the rented house are dominating in the sample. It can be concluded that the association between the residential status of the respondents and their level of satisfaction is statistically significant.

6.7 Status of ownership of share auto and sample respondents

The distribution of sample respondents according to their status of ownership of share auto is given in table 6.7

Table 6.7

Distribution of sample respondents according to their status of ownership of share auto

\begin{tabular}{|c|c|c|c|}
\hline Sl.No. & Status of ownership of share auto & Number & Percentage \\
\hline 1 & Own & 13 & 26 \\
\hline 2 & Hired & 37 & 74 \\
\hline \multicolumn{2}{|c|}{ Total } & $\mathbf{5 0}$ & $\mathbf{1 0 0}$ \\
\hline
\end{tabular}

Sample respondents belong to the hired are dominating in the sample. It can be concluded that the association between the status of ownership of share auto of the respondents and their level of satisfaction is statistically significant.

6.8 Source of finance and sample respondents

The distribution of sample respondents according to their source of finance is given in table 6.8

Table 6.8

Distribution of sample respondents according to their source of finance

\begin{tabular}{|c|c|c|c|}
\hline SI.No. & Sources of finance & Number & Percentage \\
\hline 1 & Own funds & 16 & 32 \\
\hline 2 & Other sources & 34 & 68 \\
\hline \multicolumn{2}{|c|}{ Total } & $\mathbf{5 0}$ & $\mathbf{1 0 0}$ \\
\hline
\end{tabular}

Sample respondents belong to the other sources are dominating in the sample. It can be concluded that the association between the source of finance of the respondents and their level of satisfaction is statistically significant.

\section{Problems of share auto-rickshaw driver}


Share auto rickshaw drivers encounter their problems like problem in hiring, irregular demand, no satisfactory margin, police harassment, too much renewal, and license fee quarrels among driver etc. They not only merely look as problems but they also serve as potential ground for problems to be faced by drivers.

To understand the problems of the share auto drivers, five major problems are identified and given to respondents for ranking according to their preference. Using Garrets Ranking Technique, the problems of respondents were identified, ranked and presented in table 7.1

Table 7.1

Problems of respondents

\begin{tabular}{|c|c|c|}
\hline Sl.No. & Problems & Rank \\
\hline 1. & Problem in hiring & 1 \\
\hline 2. & Unsatisfactory margin & 2 \\
\hline 3. & Working during odd hours & 3 \\
\hline 4. & Police harassment & 4 \\
\hline 5. & Too much renewal, license fee & 5 \\
\hline
\end{tabular}

This analysis has cautioned the people concerned to address the identified problems immediately and help the share auto rickshaw drivers to drive a pleasant and peaceful life.

\section{Summary of findings}

The present article assumes a greater significant and provides a valuable data for the policy makers to take corrective measures wherever necessary. The findings of the article given as follows:

i) It is known that a majority of 70 percent of share auto drivers are college educated.

ii) It is clear that a majority of 42 percent of share auto drivers are living in rented houses.

iii) It is found that a majority of 60 percent share auto drivers have expenses of per month of between Rs.500 and Rs.1,000

iv) It is disclosed that a majority of 43 percent of share auto drivers belong to the category of membership in association of AICTU

v) It is clear that a majority of 62 percent share auto drivers experienced above 5 years.

vi) It is found that the satisfaction of respondents is the highest among the respondents who belong to the other sources category.

vii) It is found from chi-square analysis that the relationship between the education qualification, religion, marital status, residential status, status of ownership and source of finance and their level of satisfaction is statistically significant.

viii) It is found that from chi-square analysis that the relationship between the age of the respondents and size of the family and their level of satisfaction is not statistically significant.

\section{Suggestions}

The following are the some major suggestion offered by the researcher based on his findings.

i) It is suggested that a separate housing scheme may be introduced for share auto drivers.

ii) It is suggested that "Share Auto-Rickshaw Drivers Co-operative Bank" may be allowed to be opened by their associations.

iii) It is suggested that "Public-police-share auto drivers meet" may be arranged frequently.

iv) It is suggested that instead of issuing driving license under general category, share auto driving license may be issued by the Road Transport Office separately.

v) It is suggested that installing of electronic meter, by made compulsory.

vi) It is suggested that a considerable amount may be earmarked every year, by the District Industries Centre (DIC) to finance share auto drivers.

\section{Conclusion}

Share auto drivers being the backbone of this transport, all their problems should be settled so as to change their mindset towards commuters, police and society at large. Some of the findings of the present article are revealing and worth considering. It is the hope of the researcher that if the suggestions given in the study are implemented in letters and spirit, the share auto drivers would not only become more public friendly. But also make this transport an indispensable one in this country.

\section{References:}

[1] www.google.com, The Hindu, The English daily newspaper online edition, Aug 23, 2008.

[2] The Hindu, English daily newspaper, July 25, 2009, p.23

[3] Ibid, June 10, 2008 